Folia Cardiologica 2019 tom $14, \mathrm{nr} 1$, strony $95-105$ DOI: 10.5603/FC.2019.0002 Copyright (C) 2019 Via Medica ISSN 2353-7752

\title{
Sakubitril/walsartan w praktyce klinicznej
}

\author{
Sacubitril/valsartan in clinical practice
}

\author{
Małgorzata Lelonek ${ }^{1}$, Paweł Rubiś ${ }^{2}$, Jakub Gierczyński ${ }^{3}$, Agnieszka Pawlak ${ }^{4,5}$ \\ ${ }^{1}$ Zakład Kardiologii Nieinwazyjnej Katedry Chorób Wewnętrznych i Kardiologii Uniwersytetu Medycznego w Łodzi \\ ${ }^{2}$ Klinika Chorób Serca i Naczyń Collegium Medicum Uniwersytetu Jagiellońskiego w Krakowie \\ ${ }^{3}$ Instytut Zarządzania w Ochronie Zdrowia Uczelni Łazarskiego w Warszawie \\ ${ }^{4}$ Instytut Medycyny Doświadczalnej i Klinicznej Polskiej Akademii Nauk w Warszawie \\ ${ }^{5}$ Klinika Kardiologii Inwazyjnej CSK MSWiA w Warszawie
}

\section{Streszczenie}

W badaniu PARADIGM-HF (Prospective comparison of ARNI with ACEI to Determine Impact on Global Mortality and morbidity in Heart Failure), wieloośrodkowym, randomizowanym badaniu klinicznym III fazy, zaprojektowanym w celu oceny długoterminowej skuteczności i bezpieczeństwa terapii LCZ696 w porównaniu z enalaprilem, udokumentowano korzyść kliniczną odnoszącą się do leku sakubitril/walsartan dla pacjentów z niewydolnością serca z obniżoną frakcją wyrzutową. Od ponad 2 lat lek Entresto ${ }^{T M}$ jest dostępny w Polsce. Niniejszy dokument stanowi praktyczny przewodnik i jest przeznaczony dla lekarzy, którzy chcieliby rozpocząć terapię tym lekiem u swoich pierwszych pacjentow oraz dla tych, którzy już mają pierwsze doświadczenia ze stosowaniem tego leku.

Słowa kluczowe: niewydolność serca z obniżoną frakcją wyrzutową, sakubitril/walsartan

Folia Cardiologica 2019; 14, 1: 95-105

\section{Wstęp}

Europejskie Towarzystwo Kardiologiczne (ESC European Society of Cardiology) w 2016 roku opublikowało nowe wytyczne dotyczące niewydolności serca (HF, heart failure) [1]. W dokumencie tym po raz pierwszy do terapii niewydolności serca z obniżoną frakcją wyrzutową (HFrEF, heart failure with reduced ejection fraction) wprowadzono nową grupę leków - antagonistów receptora AT1 dla angiotensyny II i inhibitora neprilizyny (ARNI, angiotensin receptor-nephrilysin inhibitor). Jedynym przedstawicielem ARNI jest sakubitril/walsartan (w badaniach klinicznych noszący nazwę LCZ696). Połączenie sakubitril/walsartan (produkt leczniczy Entresto ${ }^{T M}$ ) jest pierwszym dostępnym na rynku preparatem z grupy selektywnych antagonistów receptora AT1 dla angiotensyny II (walsartan) i inhibitorów neprilizyny (sakubitril).
Od ponad 2 lat preparat Entresto ${ }^{T M}$ jest dostępny w Polsce; leczy się nim około 950 pacjentów. Niniejszy dokument stanowi praktyczny przewodnik i jest przeznaczony dla lekarzy, którzy chcieliby rozpocząć terapię preparatem Entresto $^{T M}$ u swoich pierwszych pacjentow oraz tym, którzy mają już pierwsze doświadczenia z zastosowaniem tego leku. Dokument napisali eksperci klinicyści, którzy mają doświadczenie kliniczne z lekiem oraz prowadzili obserwacje długoterminowe w populacji co najmniej 40 pacjentów.

\section{Profil kliniczny i kryteria doboru pacjenta}

W badaniu PARADIGM-HF (Prospective comparison of ARNI with ACEI to Determine Impact on Global Mortality and morbidity in Heart Failure) - wieloośrodkowym, randomizowanym badaniu klinicznym III fazy, zaprojektowanym w celu oceny długoterminowej skuteczności i bezpieczeństwa 
Tabela 1. Profil kliniczny populacji badania PARADIGM-HF (na podstawie [2])

\section{HFrEF, II-IV klasa wg NYHA}

Stabilny obraz kliniczny przez ostatnie 4 tygodnie

$\mathrm{BP} \geq 100 \mathrm{~mm} \mathrm{Hg}$

Inhibitor ACE, beta-adrenolityk, MRA przez $\geq 4$ tygodnie w stabilnych dawkach

eGFR $>30 \mathrm{ml} / \mathrm{min} / 1,73 \mathrm{~m}^{2}$

Stężenie $\mathrm{K}^{+}<5,4$

Tolerancja inhibitora ACE/ARB w dawkach ekwiwalentnych do enalaprilu $\geq 10 \mathrm{mg} / \mathrm{d}$.

HFrEF (heart failure with reduced ejection fraction) - niewydolność serca z obniżoną frakcja wyrzutową; NYHA - New York Heart Association; BP (blood pressure) - ciśnienie tętnicze; ACE (angiotensin-converting enzyme) - inhibitor konwertazy angiotensyny; MRA (mineralocorticoid receptor antagonist) - antagonista receptora mineralokortykoidowego; eGFR (estimated glomerular filtration rate) - szacunkowy współczynnik przesączania kłębuszkowego; $\mathrm{K}$ - potas; ARB (angiotensin receptor blocker) - antagonista receptora AT1 dla angiotensyny II

terapii LCZ696 w porównaniu z enalaprilem, udokumentowano korzyść kliniczną z przyjmowania leku sakubitril/ /walsartan przez pacjentów z niewydolnością serca z obniżoną frakcją wyrzutową (HFrEF, heart failure with reduced ejection fraction) [2]. Badanie przeprowadzono z udziałem 8399 pacjentów z objawami w II-IV klasie według New York Heart Association (NYHA), z przewlekłą HF z obniżoną frakcją wyrzutową lewej komory (LVEF, left ventricular ejection fraction) mniejszą lub równą 40\% (zmiana na $\leq 35 \%$ od grudnia 2010 r.), którzy byli poddani pełnemu, tolerowanemu i zgodnemu z aktualnymi zaleceniami leczeniu HF. Profil kliniczny populacji badania PARADIGM-HF przedstawiono w tabeli 1.

Na podstawie wyników badania PARADIGM-HF (tab. 2) Europejska Agencja Leków (EMA, European Medicines
Agency) i amerykańska Agencja Żywności i Leków (FDA, Food and Drug Administation) zatwierdziły w 2015 roku stosowanie leku sakubitril/walsartan w leczeniu pacjentów z objawową przewlekłą HFrEF. Następnie ESC w wytycznych dotyczących HF, opublikowanych pod koniec maja 2016 roku, przyznało klasę I, poziom dowodów B, zaleceniu stosowania sakubitrilu/walsartanu zamiast inhibitora konwertazy angiotensyny (ACE, angiotensin-converting enzyme) w celu dalszego obniżenia ryzyka zgonu i hospitalizacji z powodu HF u ambulatoryjnych chorych ze stabilną HF i udokumentowaną LVEF $\leq 35 \%$, u których objawy w II-IV klasie wg NYHA utrzymują się mimo optymalnego leczenia inhibitorem ACE (lub antagonistą receptora AT1 dla angiotensyny II [ARB, angiotensin receptor blocker]), beta-adrenolitykiem i antagonistą receptora mineralokortykoidowego (MRA, mineralocorticoid receptor antagonist) [1]. Warunkiem zastosowania tego leku jest tolerancja dotychczasowego leczenia inhibitorem ACE lub ARB w dawce dobowej ekwiwalentnej do 2 razy $10 \mathrm{mg}$ enalaprilu. Szczegółowe dane na temat ekwiwalentnych do $10 \mathrm{mg}$ enalaprilu dawek inhibitorów ACE i ARB stosowanych przed zmianą leczenia na Entresto $^{T M}$ podano w tabeli 3 [3].

Należy podkreślić, że w wytycznych ESC [1] przed włączeniem leku sakubitril/walsartan wskazuje się na stabilność obrazu klinicznego w HF jako okres 4 tygodni bez zaostrzenia objawów HF, przy zachowaniu stałych dawek standardowej terapii (inhibitor ACE, beta-adrenolityk i MRA) (SoC, standard of care).

Charakterystykę kliniczną pacjenta kandydata do stosowania preparatu Entresto ${ }^{T M}$ według charakterystyki produktu leczniczego (ChPL) [4] i wyników badania PARADIGM-HF [2] zawarto w tabeli 4.

Tabela 2. Pierwszorzędowe i drugorzędowe punkty końcowe w badaniu PARADIGM-HF (na podstawie [2])

$\begin{array}{lcccc}\text { Wynik } & \begin{array}{c}\text { LCZ696 } \\ (\mathrm{n}=4187)\end{array} & \begin{array}{c}\text { Enalapril } \\ (\mathrm{n}=4212)\end{array} & \begin{array}{c}\text { Współczynnik ryzyka } \\ (95 \% \mathrm{Cl})\end{array} & \text { Wartość p } \\ \begin{array}{l}\text { Pierwszorzędowy punkt końcowy } \\ \begin{array}{l}\text { Zgon z przyczyn sercowo-naczyniowych lub } \\ \text { pierwsza hospitalizacja z powodu HF }\end{array}\end{array} & 914(21,8) & 1117(26,5) & 0,80(0,73-0,87) & <0,001 \\ \begin{array}{l}\text { Zgon z przyczyn sercowo-naczyniowych } \\ \text { Pierwsza hospitalizacja z powodu HF }\end{array} & 558(13,3) & 693(16,5) & 0,80(0,71-0,89) & <0,001 \\ \begin{array}{l}\text { Drugorzędowy punkt końcowy } \\ \text { Zgon z dowolnej przyczyny }\end{array} & 537(12,8) & 658(15,6) & 0,79(0,71-0,89) & <0,001 \\ \begin{array}{l}\text { Zmiana w KCCQ }{ }^{1} \text { w 8. miesiącu badania } \\ \text { Wystąpienie migotania przedsionków }\end{array} & -2,99 \pm 0,36 & -4,63 \pm 0,36 & 1,64(0,63-2,65) & 0,001 \\ \text { Pogorszenie funkcji nerek } & 84(3,1) & 83(3,1) & 0,97(0,72-1,31) & 0,83\end{array}$

${ }^{1}$ Kansas City Cardiomyopathy Questionnaire (KCCQ) - obejmuje zakres 0-100 pkt.; wysokie wyniki świadczą o mniejszym nasileniu objawów HF; ${ }^{2}$ całkowita liczba 2670 pacjentów w grupie stosującej LCZ696; 2638 pacjentów w grupie stosującej enalapril, u których na wizycie randomizacyjnej nie stwierdzomo migotania przedsionków, oceniano pod względem możliwości wystąpienia migotania przedsionków podczas badania; $\mathrm{Cl}$ (confidence interval) - przedział ufności; $\mathrm{HF}$ (heart failure) - niewydolność serca 
Tabela 3. Minimalne wymagane dawki inhibitora konwertazy angiotensyny (ACE, angiotensin-converting enzyme) i antagonisty receptora AT1 dla angiotensyny II (ARB, angiotensin receptor blocker) niezbędne do rozpoczęcia leczenia preparatem Entresto ${ }^{T M}$ (na podstawie [2])

$\begin{array}{lccc} & \text { Inhibitor ACE } & & \text { ARB } \\ \text { Nazwa leku } & \text { Minimalna dobowa dawka [mg] } & \text { Nazwa leku } & 16 \\ \text { Enalapril } & 10 & \text { Kandesartan } & 400 \\ \text { Kaptopril } & 100 & \text { Eprosartan } & 150 \\ \text { Cilazapril } & 2,5 & \text { Irbesartan } & 50 \\ \text { Fosinopril } & 20 & \text { Losartan } & 10 \\ \text { Lisinopril } & 10 & \text { Olmesartan } & 40 \\ \text { Moeksipril } & 7,5 & \text { Telmisartan } & 160 \\ \text { Perindopril } & 4 & \text { Walsartan } & \\ \text { Chinapril } & 20 & & \\ \text { Ramipril } & 5 & & \\ \text { Trandolapril } & 2 & & \end{array}$

Tabela 4. Charakterystyka pacjenta kandydata do przyjmowania antagonistów receptora AT1 dla angiotensyny II i inhibitora neprilizyny (ARNI, angiotensin receptor-nephrilysin inhibitor) według charakterystyki produktu leczniczego (ChPL) i badania PARADIGM-HF

\section{Z niewydolnością serca z obniżoną frakcją wyrzutową}

Optymalnie leczony standardową terapią w HF wg wskazań (inhibitor ACE/beta-adrenolityk/MRA)

W stanie stabilnym, $\geq 4$ tygodnie na optymalnym leczeniu HF

Z utrzymującymi się objawami HF

Z ciśnieniem skurczowym $>100$ mm Hg

Bez ciężkich zaburzeń funkcji nerek (eGFR $>30 \mathrm{ml} / \mathrm{min} / 1,73 \mathrm{~m}^{2}$ )

Ze stężeniem potasu w surowicy $<5,4 \mathrm{mmol} / \mathrm{l}$

Bez obrzęku naczynioruchowego w wywiadzie

Bez ciężkiej niewydolności wątroby

ACE (angiotensin-converting enzyme) - inhibitor konwertazy angiotensyny; MRA (mineralocorticoid receptor antagonist) - antagonista receptora mineralokortykoidowego; eGFR (estimated glomerular filtration rate) - szacunkowy współczynnik przesączania kłębuszkowego

\section{Jak zainicjować i optymalizować leczenie sakubitrilem/walsartanem}

Kluczowym elementem przy rozpoczęciu terapii lekiem sakubitril/walsartan jest właściwa identyfikacja pacjenta kandydata, co przedstawiono w poprzedniej części artykułu. Podstawą rozpoczęcia terapii jest głównie znajomość wartości ciśnienia tętniczego BP (blood pressure). Schemat ukazany na rycinie 1 przedstawia zasadę doboru dawki inicjującej terapię (ryc. 1).

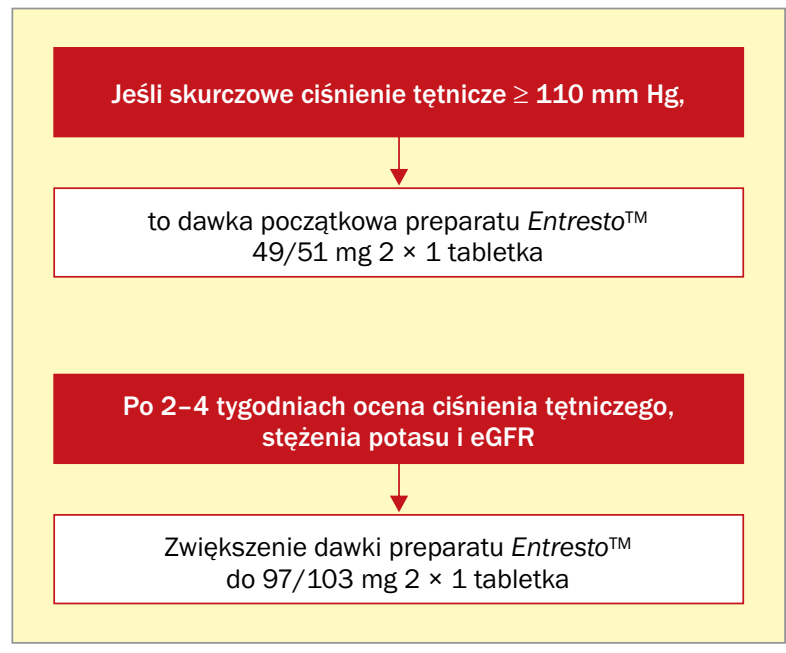

Rycina 1. Zasada doboru dawki preparatu Entresto ${ }^{T M}$ przy rozpoczynaniu leczenia; eGFR (estimated glomerular filtration rate) szacunkowy współczynnik przesączania kłębuszkowego

Zgodnie z CHPL [4] nie należy włączać leczenia preparatem Entresto ${ }^{T M}$ wcześniej niż po $36 \mathrm{~h}$ od przyjęcia ostatniej dawki inhibitora ACE, ze względu na możliwe ryzyko obrzęku naczynioruchowego.

Do momentu włączenia pierwszej dawki Entresto ${ }^{T M}$ chory może bezpiecznie pozostawać bez terapii inhibitorem ACE przez 36 h [4]. W przypadku wcześniejszego stosowania ARB nie jest wymagana przerwa w leczeniu sartanami. Sakubitril/walsartan można włączyć kolejnego dnia w miejsce ARB [4]. Przed każdą intensyfikacją dawki konieczne jest sprawdzenie stężenia potasu i parametrów nerkowych. 
Rozpoczęcie leczenia od najmniejszej dawki Entresto ${ }^{T M}$, tj. 24/26 mg 2 razy/dobe, jest zarezerwowane dla szczególnych grup pacjentów [4]:

- pacjentów, którzy nie przyjmowali wcześniej inhibitora ACE ani ARB;

- pacjentów stosujących małą dobową dawkę enalaprilu, tj. nie większą niż $10 \mathrm{mg}$ lub walsartanu mniejszą lub równą 160 mg albo równoważną terapeutycznie dawkę innego inhibitora ACE czy ARB;

- pacjentów z wartościami skurczowego ciśnienia tętniczego (SPB, systolic blood pressure) większymi lub równymi 100 do $110 \mathrm{~mm} \mathrm{Hg;}$

- z ciężka niewydolnością nerek (szacunkowy współczynnik przesączania kłębuszkowego [eGFR, estimated glomerular filtration rate] $<30 \mathrm{ml} / \mathrm{min} / 1,73 \mathrm{~m}^{2}$ );

- z umiarkowaną niewydolnością wątroby (klasa B wg skali Childa-Pugha);

z zasadą powolnego podwojenia dawki po 3-4 tygodniach zależnie od tolerancji leku oraz wyników badań eGFR i stężenia potasu w surowicy krwi.

Nie należy rozpoczynać leczenia lekiem sakubitril/ /walsartan u pacjentów z SBP poniżej 100 mm Hg [4].

U pacjentów z niskim BP warto przeanalizować dotychczasowe leczenie przed rozpoczęciem terapii Entresto ${ }^{T M}$, a także w trakcie leczenia zdecydować o przydatności czy konieczności stosowania innych leków o działaniu hipotensyjnym. Do takich leków należą: azotany, antagoniści wapnia, diuretyki. Warto w tym miejscu przypomnieć, że sakubitril/walsartan wykazuje działanie moczopędne, można zatem zmniejszyć dawkę diuretyku, zamienić na długodziałający lub zrezygnować z terapii moczopędnej, jeśli u pacjenta nie występują objawy przewodnienia.

\section{Kontynuacja leczenia} i jego monitorowanie

We wcześniejszych doświadczeniach leczenia chorych lekiem sakubitril/walsartan najczęściej dawkę początkową stanowiła tabletka 24/26 mg podawana 2 razy/ dobę. Było to podyktowane włączaniem leku u chorych z istotnie zaawansowaną, objawową HF, u których BP pozostaje niskie ( $\geq 100-110 \mathrm{~mm} \mathrm{Hg}$ ) oraz brakiem doświadczenia, a zatem z dużą ostrożnością. Należy jednak podkreślić, że u pacjentów z niższa klasą według NYHA (II) i dobrymi wartościami BP (> $110 \mathrm{~mm} \mathrm{Hg}$ ) zalecana dawka początkowa to tabletka $49 / 51 \mathrm{mg}$ podawana 2 razy/dobę. Zdobywane doświadczenie sprawia, że lekarze coraz częściej sięgają po tę dawkę jako początkową dla swoich chorych.

Jeśli u pacjenta wystąpią problemy z tolerancją leku pod postacią SBP obniżonego do wartości nieprzekraczającej 95 mm Hg, objawy niedociśnienia, hiperkaliemia, zaburzenia czynności nerek, to zaleca się dostosowanie dawek jednocześnie podawanych leków, czasowe zmniejszenie dawki lub przerwanie podawania skubitrilu/walsartanu. Dostosowywanie dawki leku powinno być poprzedzone oceną stanu klinicznego chorego, tj. pomiarem BP, oceną stężenia potasu oraz funkcji nerek (wartość kreatyniny, eGFR) i wątroby (aktywność aminotransferazy asparaginianowej [AspAT, aspartate aminotransferase] i aminotransferazy alaninowej [AIAT, alanine aminotransferase]).

Należy unikać stosowania leku u pacjentów ze stężeniem potasu w surowicy ponad 5,4 mmol/I lub SBP mniejszym niż 100 mm Hg, aczkolwiek doświadczenie ze stosowaniem tego leku w Polsce wskazuje, że u chorych z SBP poniżej $100 \mathrm{~mm} \mathrm{Hg}$, bez objawów również warto rozważyć zastosowanie leku pod warunkiem zachowania szczególnej ostrożności.

$\mathrm{Na}$ rycinie 2 przedstawiono schemat zwiększania dawki leku sakubitril/walsartan w zależności od dawki początkowej.

\section{Wpływ terapii na stan kliniczny pacjenta}

Z doświadczeń klinicznych wynika, że najwcześniejszym i najbardziej dominującym elementem jest poprawa jakości życia zgłaszana przez pacjentów po włączeniu preparatu Entresto $^{T M}[5,6]$. Zjawisko to u wielu pacjentów pojawia się stosunkowo szybko, już w pierwszym miesiącu terapii, i jest związane z obniżeniem stężenia N-końcowego fragmentu propeptydu natriuretycznego typu B (NT-proBNP, N-terminal pro-B-type natriuretic peptide) [7]. Należy przypomnieć, że peptyd natriuretyczny typu B (BNP, B-type natriuretic peptide) jako substrat neprilizyny nie jest właściwym biomarkerem HF u pacjentów leczonych lekiem sakubitril/ /walsartan. Stężenie NT-proBNP pozwala ocenić efekt terapeutyczny pod postacią obniżenia stężenia peptydu natriuretycznego.

Właściwy dobór profilu klinicznego pacjenta do leczenia preparatem Entresto ${ }^{T M}$ gwarantuje bezpieczeństwo terapii. Rzadko lek wymaga zmniejszenia dawki z powodu hipotonii, a jeszcze rzadziej z powodu parametrów nerkowych czy podwyższenia stężenia potasu.

U chorych, którzy byli hospitalizowani z powodu zaostrzenia HF, podczas terapii Entresto ${ }^{T M}$ wydłuża się czas do kolejnej hospitalizacji oraz długo pozostają w stabilnym stanie klinicznym i nie wymagają hospitalizacji czy zwiększania dawek leków moczopędnych.

Ostatni rok zaowocował licznymi publikacjami opartymi na RWD (ang. real world data) i RWE (ang. real world evidence) dotyczącymi schematu leczenia HFrEF sakubitrilem/walsartanem. Wyniki analizy rzeczywistych danych z praktyki klinicznej potwierdzają korzyści terapii sakubitrilem/walsartanem u stabilnych pacjentów z HFrEF. Korzyści te pojawiają się wcześnie i utrzymują. W kolejnej części przedstawiono wybrane prace na ten temat. 


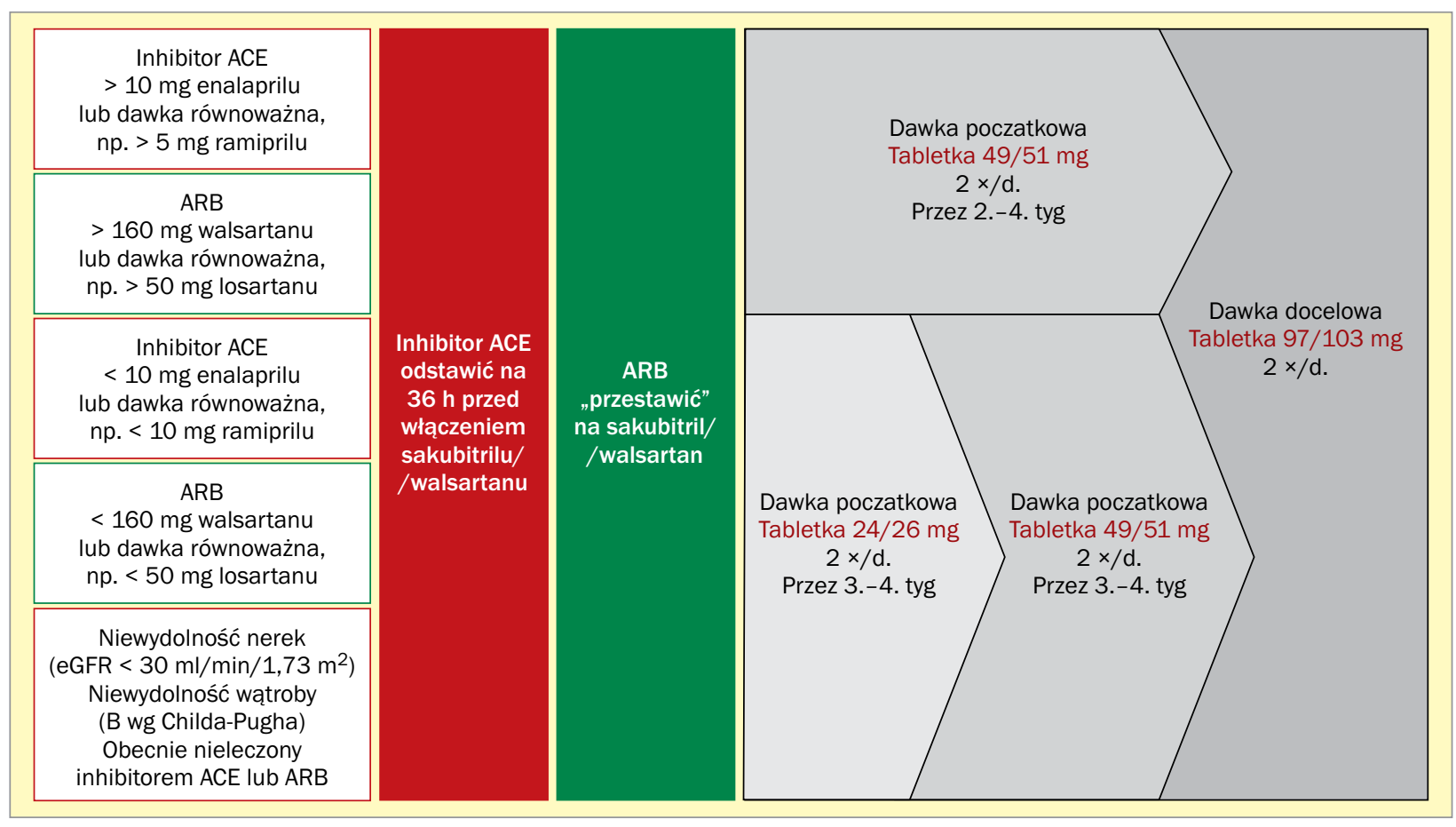

Rycina 2. Dobór dawki początkowej i eskalacja terapii lekiem sakubitril/walsartan u pacjentów z niewydolnością serca; ACE (angiotensin-converting enzyme) - inhibitor konwertazy angiotensyny; ARB (angiotensin receptor blocker) - antagonista receptora AT1 dla angiotensyny II; eGFR (estimated glomerular filtration rate) - szacunkowy współczynnik przesączania kłębuszkowego

\section{RWD i RWE dla modelu opieki oraz leczenia farmakologicznego w HF}

RWD to dane pochodzące z badań prowadzonych w warunkach rzeczywistej praktyki klinicznej, natomiast RWE to dowody skuteczności pochodzące z badań prowadzonych w warunkach rzeczywistej praktyki klinicznej [8]. Dowody skuteczności pochodzące z badań prowadzonych w warunkach rzeczywistej praktyki klinicznej są coraz częściej wykorzystywane wraz z danymi z randomizowanych badań klinicznych (RCT, randomised clinical trial) do podejmowania decyzji dotyczących leczenia [9, 10]. Większość z 202 badań opublikowanych w latach 2013-2016 miało charakter badań obserwacyjnych przeprowadzonych w warunkach rzeczywistej praktyki kardiologicznej. Średni rozmiar próby wszystkich badań wyniósł 5152 (2417-32 890), a mediana okresu badania - 55 miesięcy $(33,0-72,0)$. Analizowano przede wszystkim przeżywalność chorych, długość hospitalizacji i koszty całkowite związane z HF [11]. Zgodnie z analizą Greene i wsp. [12] dotyczącą danych uzyskanych z rejestru The Change the Management of Patients with Heart Failure (CHAMP-HF), obejmującego 3518 chorych z HF leczonych w 150 ośrodkach klinicznych w Stanach Zjednoczonych, stwierdzono, że gdyby standardy terapeutyczne były optymalnie wdrażane, a leki właściwie dawkowane, to każdego roku można by uniknąc dziesiątek tysięcy dodatkowych zgonów wśród pacjentów z HF.
Z retrospektywnej bazy danych z rzeczywistej praktyki klinicznej w Niemczech u 1643 pacjentów z HFrEF po 90 i 180 dniach od rozpoczęcia leczenia sakubitrilem/ /walsartanem odnotowano odwrócenie tendencji do pogarszania się klasy według NYHA [13] i obniżenie stężenia NT-proBNP, a wielkość spadku była podobna do obserwowanej w badaniu PARADIGM-HF Germany [13, 14]. W badaniu typu RWE przeprowadzonym przez Canu i wsp. [15] w 2017 roku we Francji w grupie 200 pacjentów leczonych sakubitrilem/walsartanem w warunkach rzeczywistej praktyki klinicznej stwierdzono poprawę w klasie według NYHA i w zakresie wydolności wysiłkowej. Trzeba jednak dodać, że większość pacjentów rozpoczęła leczenie i pozostała przy najmniejszej dawce preparatu Entresto ${ }^{T M}$, co wskazuje na dalsze możliwości poprawy klinicznej poprzez zwiększenie dawki leku.

Grupa Bastien i wsp. [16] u 45\% pacjentów spośród 276 chorych w Kanadzie włączonych do terapii sakubitrilem/walsartanem w warunkach rzeczywistej praktyki klinicznej odnotowała poprawę parametrów klinicznych i wskaźników jakości życia po 4 tygodniach, natomiast $56 \%$ pacjentów z tej grupy zgłosiło podobne zmiany po 12 tygodniach leczenia. Choć brak grupy porównawczej ogranicza interpretację, to wyniki wskazują na potencjalną poprawę wyników uzyskanych w dwóch z trzech zatwierdzonych kwestionariuszy jakości życia (MLHFQ; Minnesota Living with HF Questionnaire) w pierwszych 12 tygodniach 
leczenia sakubitrilem/walsartanem [16]. W Belgii w grupie 120 chorych z HF w praktyce klinicznej poddanych terapii sakubitrilem/walsartanem wykazano trend obniżenia ryzyka hospitalizacji z powodu HF i śmiertelności [17].

Według Murray i wsp. [18] w badaniu w warunkach rzeczywistej praktyki klinicznej wśród 131 pacjentów w Irlandii wykazano skuteczność sakubitrilu/walsartanu w poprawie odnoszącej się do objawów i biomarkerów ryzyka sercowo-naczyniowego oraz obniżenie stężenia NT-proBNP, przy jednoczesnym zmniejszeniu zapotrzebowania na terapię diuretyczną w rzeczywistej populacji. Nietolerancja terapii preparatem Entresto $^{T M}$ była mała. W Polsce Oleksy i wsp. [19] stwierdzili, że stosowanie sakubitrilu/walsartanu w warunkach opieki ambulatoryjnej w naszym kraju u 28 pacjentów z HFrEF jest bezpieczne i wiąże się z istotną poprawą kliniczną. Entresto ${ }^{T M}$ stosowano u pacjentów w I-III czynnościowej klasie według NYHA. U 25 (89,2\%) chorych terapię lekiem sakubitril/ /walsartan rozpoczęto od najmniejszej dawki (24/26 mg $2 \times /$ d.). Podczas okresu obserwacji u pacjentów leczonych sakubitrilem/walsartanem obserwowano ograniczenie objawów HF oceniane na podstawie klasy według NYHA $(p=0,001$ ), istotne obniżenie stężenia NT-proBNP (średnio z 2900 do 2270 pg/ml; $p=0,008$ ) oraz poprawę tolerancji wysiłku fizycznego, które wystąpiły szybko po rozpoczęciu leczenia - średnio po 28 dniach.

Biorąc pod uwage rzeczywiste dane w zakresie kosztów terapii w warunkach rzeczywistej praktyki klinicznej wśród 200 chorych z HFrEF w Stanach Zjednoczonych [20], wykazano, że stosowanie Entresto ${ }^{T M}$ obniżyło koszty opieki zdrowotnej u pacjentów z HF. Stosowanie sakubitrilu/walsartanu wiązało się z poprawą stanu zdrowia i zmniejszeniem liczby hospitalizacji w ciągu 4 miesięcy od rozpoczęcia leczenia tym lekiem.

\section{Współpraca pacjent-lekarz}

Kluczowym elementem prawidłowej opieki na pacjentem z chorobą przewlekłą, jaką jest HF, stanowi wytworzenie możliwie jak najlepszej relacji lekarz-pacjent. Z jednej strony lekarz, ze względu na swoją wiedzę i umiejętności, będzie miał oczywistą przewagę merytoryczną nad pacjentem, z drugiej strony chodzi o to, aby pacjent w miare możliwości rozumiał i akceptował postępowanie lekarza. Z perspektywy pacjenta prawidłowe postępowanie w HF to nie tylko systematyczne przyjmowanie przepisanych leków, ale także, a może przede wszystkim, dostosowanie swojego życia do zmienionej sytuacji związanej z chorobą. W wyniku odpowiedniej edukacji i przekazania informacji na temat prozdrowotnych zachowań pacjent powinien czuć się współodpowiedzialny za przebieg swojej choroby. Opracowano wiele zasad optymalnego postępowania niefarmakologicznego, z których kilka ma kluczowe znaczenie (tab. 5).
Te i inne zasady pacjentowi powinien przekazać lekarz prowadzący, ponieważ z jednej strony uczy pacjenta żyć ze swoją chorobą, a z drugiej umożliwia nawiązanie „ponadprzeciętnych” relacji z pacjentem. Pacjent, który zna swojego lekarzowi i mu ufa, znacznie łatwej przyjmie kolejne zalecenia od lekarza, w tym zmianę czy wprowadzenie nowych leków. Mając na uwadze niezaprzeczalne korzyści z terapii lekiem sakubitril/walsartan u chorych z HFrEF, należy dążyć do wprowadzania nowoczesnego leczenia u jak największej liczby chorych. W praktyce oznacza to przedstawienie informacji o leku sakubitril/ /walsartan każdemu wykazującemu objawy (II-IV klasa wg NYHA) pacjentowi z przewlekłą HFrEF i zaproponowanie wprowadzenia nowego leczenia. Co więcej, takie postępowanie jest rekomendowane w aktualnych wytycznych ESC z 2016 roku. W tym miejscu należy mieć świadomość, że istnieją odrębności w spojrzeniu na tą samą kwestię między europejskimi a amerykańskimi kardiologami, ponieważ w wytycznych Amerykańskiego Towarzystwa Kardiologicznego (AHA, American Heart Association) dodatkowo rekomenduje się wprowadzenie terapii lekiem sakubitril/ /walsartan u pacjentów z nowo rozpoznaną HFrEF, którzy dotychczas nie byli leczeni inhibitorem ACE (ARB). Nawet jednak przyjmując bardziej „konserwatywne” europejskie podejście, wciąż mamy do czynienia z ogromną liczbą pacjentów. Świadomy pacjent z HFrEF, który przebył zaostrzenie (zaostrzenia) HF, wymagające pilnej hospitalizacji, będzie się starał zrobić „wszystko”, by uniknąć kolejnego takiego epizodu. Dlatego umiejętne przedstawienie pacjentowi po świeżej dekompensacji nowoczesnego sposobu leczenia sakubitrilem/walsartanem, mogącego uchronić przed kolejnym zaostrzeniem, może przynieść większy skutek niż przedstawienie tej samej informacji pacjentowi, który czuje się względnie dobrze (I-II klasa wg NYHA) poddany dotychczasowemu leczeniu.

\section{Problemy związane z procesem włączenia leku}

Każde rozpoczęcie po raz pierwszy nowej terapii, w tym sakubitrilem/walsartanem, wiąże się z pewnymi obawami lekarza, który decyduje się na ten krok. Czym innym jest bowiem słuchać wykładów czy czytać publikacje medyczne na temat danego preparatu, a czym innego być „sam na sam” z pacjentem i jego, a także swoimi, wątpliwościami. W tym miejscu należy przypomnieć niedawne w gruncie rzeczy obawy, jakie dotyczyły włączania antagonistów receptorów beta-adreneragicznych u chorych z objawową HFrEF. Po kilkunastu latach stosowania skuteczność i bezpieczeństwo terapii beta-adrenolitykami, nawet w bardzo zaawansowanych postaciach HFrEF, została bezsprzecznie udowodniona i obecnie nikt nie ma wątpliwości odnośnie celowości takiej terapii. Jednoczeżnie nie może to oznaczać bezkrytycznego szafowania tymi lekami niezależnie od sytuacji klinicznej. 
Tabela 5. Zasady niefarmakologicznego postępowania w niewydolności serca (na podstawie [1])

\begin{tabular}{|c|c|}
\hline $\begin{array}{l}\text { Objawy chorobowe/stany kliniczne, na które odpowiednio } \\
\text { wyedukowany pacjent jest w stanie sam zareagować }\end{array}$ & Co pacjent może wykonać samodzielnie? \\
\hline $\begin{array}{l}\text { Masa ciała: } \\
\text { - } \quad \text { zwiększenie ( } \uparrow \text { zatrzymywanie wody) } \\
\text { - } \quad \text { zmniejszenie (odwodnienie, kacheksja, } \\
\quad \text { proces nowotworowy) }\end{array}$ & $\begin{array}{l}\text { - } \quad \uparrow \text { dawki diuretyku (o 2-4 tabl.) } \\
\text { - } \quad \downarrow \text { dawki diurtyku i/lub } \uparrow \text { podaży płynów } \\
\text { - } \quad \text { Zaawansowana niewydolność serca, opieka hospicyjna } \\
\text { - } \quad \text { Poddanie się pilnej diagnostyce onkologicznej }\end{array}$ \\
\hline $\begin{array}{l}\text { Ciśnienie tętnicze } \\
\dot{-} \quad \uparrow(\text { (zwiększone) } \\
\cdot \quad \downarrow \text { (zmniejszone } \pm \text { objawy) }\end{array}$ & $\begin{array}{l}\text { - } \quad \text { Dodatkowe przyjęciecie leków } \downarrow \text { ciśnienie } \\
\text { - } \quad \uparrow \text { podaży płynów } \\
\text { - } \quad \text { Zaostrzenie niewydolności serca } \rightarrow \text { pilna pomoc lekarska }\end{array}$ \\
\hline Ryzyko infekcji & $\begin{array}{l}\text { - W okresach } \uparrow \text { ryzyka infekcji w miarę możliwości unikanie } \\
\text { dużych skupisk ludzi (publiczne środki transportu) } \\
\text { - Profilaktyczne szczepienia }\end{array}$ \\
\hline Szybka, nierówna praca serca & $\begin{array}{l}\text { - Duże prawdopodobieństwo napadu migotania przedsionków } \\
\rightarrow \text { pilna pomoc lekarska }\end{array}$ \\
\hline Systematyczne przyjmowanie przepisanych leków & $\begin{array}{l}\text { - Edukacja } \\
\text { - Niedoprowadzanie do sytuacji braku leków w domu }\end{array}$ \\
\hline Unikanie alkoholu & $\begin{array}{l}\text { - } \text { Brak korzyści zdrowotnych } \\
\text { - } \quad \text { Sprzyjanie zaostrzeniom niewydolności serca }\end{array}$ \\
\hline Wahania nastroju (reakcje depresyjne) & $\begin{array}{l}\text { - Częste u chorych z niewydolnością serca } \\
\text { - Konieczna konsultacja - psychoterapia, leki }\end{array}$ \\
\hline
\end{tabular}

Tabela 6. Przeciwwskazania do terapii sakubitrilem/walsartanem i choroby/sytuacje kliniczne, w przypadku których należy zachować szczególną ostrożność w trakcie terapii tym lekiem

\begin{tabular}{|c|c|}
\hline U kogo nie należy włączać sakubitrilu/walsartanu? & $\begin{array}{l}\text { U kogo należy zachować szczególną ostrość podczas włączania } \\
\text { i terapii sakubitrilem/walsartanem? }\end{array}$ \\
\hline Znana/udokumentowana nadwrażliwość na sakubitril/walsartan & $\begin{array}{l}\text { Przewlekle utrzymujące się niedociśnienie tętnicze (hipotonia, } \\
\text { ciśnienie skurczowe < } 100 \mathrm{~mm} \mathrm{Hg} \text { ) }\end{array}$ \\
\hline $\begin{array}{l}\text { Jednoczesne stosowanie inhibitora ACE (bezwzględna konieczość } \\
\text { zachowania } \geq 36 \text {-godz. przerwy między ostatnią dawką inhibitora } \\
\text { ACE a rozpoczęciem terapii sakubitrilem/walsartanem) }\end{array}$ & $\begin{array}{l}\text { Ciężkie zaburzenia czynności nerek } \\
\text { (wyliczony GFR < } 30 \mathrm{ml} / \mathrm{min} / 1,73 \mathrm{~m}^{2} \text { ) }\end{array}$ \\
\hline $\begin{array}{l}\text { Wcześniejszy obrzęk naczynioruchowy w trakcie terapii inhibitorem } \\
\text { ACE i/lub ARB }\end{array}$ & Hiperkaliemia $\left(\mathrm{K}^{+}\right.$w surowicy $\left.>5,4 \mathrm{mmol} / \mathrm{l}\right)$ \\
\hline Obrzęk naczynioruchowy w wywiadzie & Udokumentowane zwężenie tętnicy nerkowej \\
\hline $\begin{array}{l}\text { Ciężkie zaburzenia czynności wątroby, marskość wątroby i cholesta- } \\
\text { za żółciowa (stopień C wg skali Child-Pugh) }\end{array}$ & Aktualne zaostrzenie niewydolności serca (IV klasa wg NYHA) \\
\hline Ciąża (podobnie jak inhibitor ACE i ARB) & $\begin{array}{l}\text { Umiarkowane zaburzenia czynności wątroby (stopień B wg skali } \\
\text { Childa-Pugha, 2-krotne zwiększenie wartości AspAT/AIAT) }\end{array}$ \\
\hline
\end{tabular}

Obecnie podobnie wygląda sytuacja z sakubitrilem/ /walsartanem, ponieważ w Polsce jesteśmy w przededniu „rewolucji” i zmiany dotychczasowego paradygmatu opartego na stosowanej powszechnie terapii inhibitorami ACE, rzadziej ARB, na rzecz sakubitrilu/walsartanu. Jednoznaczne przeciwwskazania, a także choroby i inne stany kliniczne, które uniemożliwiają/utrudniają terapię sakubitrilem/walsartanem, przedstawiono w tabeli 6 , natomiast najczęstsze powikłania terapii i sposoby postępowania - w tabeli 7 .

Na początku swojej „przygody” z sakubitrilem/walsartanem, zwłaszcza w lecznictwie ambulatoryjnym, należy pomyśleć o pacjentach w II-III klasie według NYHA, bez ciężkich uszkodzeń narządowych, zwłaszcza nerkowych i wątroby, bez hipotonii, a pewnie także o pacjentach, których znamy i mamy z nimi dobre relacje (np. włączenie 
Tabela 7. Najczęstsze działania niepożądane terapii sakubitrilem/walsartanem i sposoby postępowania

\begin{tabular}{|c|c|}
\hline $\begin{array}{l}\text { Jakich działań niepożądanych można się spodzie- } \\
\text { wać, włączając terapię sakubitrilem/walsartanem? }\end{array}$ & $\begin{array}{l}\text { Sposoby postępowania w celu prewencji/leczenia najczęstszych działań } \\
\text { niepożądanych podczas terapii sakubitrilem/walsartanem }\end{array}$ \\
\hline $\begin{array}{l}\text { Hipotonia (ciśnienie skurczowe < } 100 \mathrm{~mm} \mathrm{Hg} \text { ) } \\
\text { - zwykle bezobjawowa, rzadko objawowa }\end{array}$ & $\begin{array}{l}\text { Doprowadzenie do optymalnego bilansu wodno-elektrolitowego - euwolemia } \\
\text { (unikanie odwodnienia i przewodnienia, optymalizacja leczenia diuretycznego } \\
\text { - odstawienie/zmniejszenie dawek diuretyków pętlowych) }\end{array}$ \\
\hline $\begin{array}{l}\text { Pogorszenie funkcji nerek } \\
\left(\downarrow \text { eGFR }<30 \mathrm{ml} / \mathrm{min} / 1,73 \mathrm{~m}^{2}\right)\end{array}$ & $\begin{array}{l}\text { W trakcie intensywnej terapii odwadniającej stosunkowo często dochodzi do } \\
\text { przejściowego pogorszenia czynności nerek } \rightarrow \text { regularne monitorowanie i opty- } \\
\text { malizacja nawodnienia pacjenta }\end{array}$ \\
\hline \multirow[t]{3}{*}{$\uparrow \mathrm{K}^{+}>5,4 \mathrm{mmol} / \mathrm{l}$} & Regularne monitorowanie \\
\hline & Optymalizacja nawodnienia pacjenta \\
\hline & Standardowe postępowanie farmakologiczne w przypadku poważnej hiperkaliemii \\
\hline
\end{tabular}

eGFR (estimated ǵlomerular filtration rate) - szacunkowy współczynnik przesączania kłębuszkowego; $\mathrm{K}$ - potas

Tabela 8. Łączenie leku sakubitrilu/walsartanu z innymi lekami często stosowanymi u chorych z niewydolnością serca

\begin{tabular}{|c|c|c|c|}
\hline Lek & Terapia skojarzona & Możliwe powikłanie & Postępowanie celem uniknięcia powikłań \\
\hline Inhibitor ACE & Przeciwwskazana & Obrzęk naczynioruchowy & $\begin{array}{l}\text { Wstrzymać podaż inhibitora ACE na } 36 \mathrm{~h} \\
\text { przed podaniem Entresto } \\
\text { Włączyć inhibitor ACE po } 36 \mathrm{~h} \text { od przerwania } \\
\text { terapii Entresto }{ }^{T M}\end{array}$ \\
\hline Aliskiren & $\begin{array}{l}\text { Przeciwwskazana/ } \\
\text { /niezalecana }\end{array}$ & $\begin{array}{l}\text { Niedociśnienie, hiperkalie- } \\
\text { mia i pogorszenie czynno- } \\
\text { ści nerek }\end{array}$ & $\begin{array}{l}\text { Nie stosować u chorych na cukrzyce, z eGFR } \\
<60 \mathrm{ml} / \mathrm{min} / 1,73 \mathrm{~m}^{2}\end{array}$ \\
\hline ARB & Niezalecana & Niedociśnienie & $\begin{array}{l}\text { Entresto }{ }^{T M} \text { zawiera ARB } \\
\text { Monitorowanie BP }\end{array}$ \\
\hline Statyny & Zachować ostrożność & $\begin{array}{l}\uparrow \text { stężenia statyn i ich me- } \\
\text { tabolitów }\end{array}$ & $\begin{array}{l}\text { Monitorowanie stężeń cholesterolu, CPK, } \\
\text { AspAT, AIAT }\end{array}$ \\
\hline PDE5-I & Zachować ostrożność & Niedociśnienie & Monitorowanie BP \\
\hline Potas, leki $\uparrow$ stężenie $\mathrm{K}$ & Zachować ostrożność & Hiperkaliemia & Monitorowanie stężenia potasu w surowicy \\
\hline $\begin{array}{l}\text { NLPZ, selektywne inhibi- } \\
\text { tory COX-2 }\end{array}$ & Zachować ostrożność & Uszkodzenie funkcji nerek & Monitorowanie czynności nerek \\
\hline Furosemid & Zachować ostrożność & $\begin{array}{l}\text { Uopośledzenie funkcji } \\
\text { nerek } \\
\text { Niedociśnienie, } \downarrow \text { stężenie } \\
\text { furosemidu }\end{array}$ & $\begin{array}{l}\text { Monitorowanie czynności nerek } \\
\text { Monitorowanie BP }\end{array}$ \\
\hline Azotany & Zachować ostrożność & $\uparrow$ czynność akcji serca & Monitorowanie HR \\
\hline Metformina & Zachować ostrożność & $\begin{array}{l}\uparrow \text { stężenie meforminy } \\
\text { o } 23 \%\end{array}$ & Monitorowanie stężenia glukozy \\
\hline Lit & Zachować ostrożność & & $\begin{array}{l}\text { Monitorowanie stanu klinicznego pacjenta, } \\
\text { wartości potasu, kreatyniny i eGFR }\end{array}$ \\
\hline $\begin{array}{l}\text { Antybiotyki (z grupy } \\
\text { rifampicyny) }\end{array}$ & Zachować ostrożność & $\begin{array}{l}\uparrow \text { stężenie LBQ657 lub } \\
\text { walsartanu }\end{array}$ & $\begin{array}{l}\text { Monitorowanie stanu klinicznego pacjenta, } \\
\text { wartości potasu, kreatyniny i eGFR }\end{array}$ \\
\hline Cyklosporyna & Zachować ostrożność & $\begin{array}{l}\uparrow \text { stężenie LBQ657 lub } \\
\text { walsartanu }\end{array}$ & $\begin{array}{l}\text { Monitorowanie stanu klinicznego pacjenta, } \\
\text { wartości potasu, kreatyniny i eGFR }\end{array}$ \\
\hline $\begin{array}{l}\text { Leki przeciwwirusowe } \\
\text { (ritonawir) }\end{array}$ & Zachować ostrożność & $\begin{array}{l}\uparrow \text { stężenie LBQ657 lub } \\
\text { walsartanu }\end{array}$ & $\begin{array}{l}\text { Monitorowanie stanu klinicznego pacjenta, } \\
\text { wartości potasu, kreatyniny i eGFR }\end{array}$ \\
\hline
\end{tabular}


leku po raz pierwszy u pacjenta będącego po raz pierwszy w poradni może być problematyczne).

Decydując się na rozpoczęcie terapii sakubitrilem/ /walsartanem po raz pierwszy, należy przeprowadzić szczegółową rozmowę z pacjentem i poinformować go o ewentualnych działaniach niepożądanych, należy zmierzyć BP, ocenić czynność nerek (również stężenie potasu) i wątroby. Ponadto u pacjenta odwodnionego i przyjmującego duże dawki diuretyków pętlowych ryzyko objawowej hipotonii jest znacznie zwiększone.

Należy podkreślić, że z jednej strony dotychczasowe doświadczenia z sakubitrilem/walsartanem w Polsce są bardzo dobre i u odpowiednio dobranych, a następnie właściwie prowadzonych chorych bardzo rzadko obserwuje się jakiekolwiek działania niepożądane. Z drugiej strony nawet u optymalnie prowadzonych chorych mogą wystąpić działania niepożądane terapii, takie jak hipotonia, które mogą być skutkiem między innymi ciężkiej choroby serca.

\section{Bezpieczeństwo terapii}

Jak bezpiecznie łączyć sakubitril/

/walsartan z innymi lekami?

Zarówno badania kliniczne, jak i praktyka kliniczna wskazuja, że lek sakubitril/walsartan jest bezpieczny i dobrze tolerowany przez chorych. Skubitril/walsartan można z powodzeniem łączyć z innymi produktami leczniczymi stosowanymi w terapii chorych z HF, z wyjątkiem inhibitorów ACE i inhibitorów reniny (aliskiren) $\mathrm{u}$ chorych z niewydolnością nerek (eGFR < $60 \mathrm{ml} / \mathrm{min} / 1,73 \mathrm{~m}^{2}$ ) i cukrzycą. Leczenie skojarzone sakubitrilem/walsartanem i inhibitorem ACE jest przeciwwskazane ze względu na ryzyko obrzęku naczynioruchowego. W populacji pacjentów z HF, ale bez cukrzycy i z niewydolnością nerek (eGFR $<60 \mathrm{ml} / \mathrm{min} / 1,73 \mathrm{~m}^{2}$ ) aliskiren nie jest przeciwskazany, nie zaleca się jednak terapii skojarzonej pod postacią sakubitrilu/walsartanu i aliskirenu. Nie należy również stosować sakubitrilu/walsartanu jednocześnie z innymi inhibitorami receptora dla angiotensyny.

Tabela 9. Zastosowanie sakubitrilu/walsartanu w grupach pacjentów wymagających zwiększonej ostrożności

Pacjenci z niedociśnieniem:

- ciśnienie tętnicze $>110 \mathrm{~mm} \mathrm{Hg}$

- ciśnienie tętnicze $\geq 100$ do $\leq 110 \mathrm{~mm} \mathrm{Hg}$

- ciśnienie tętnicze < $100 \mathrm{~mm} \mathrm{Hg}$

Pacjenci z zaburzeniami czynności nerek:

- eGFR $\geq 60$ do $<90 \mathrm{ml} / \mathrm{min} / 1,73 \mathrm{~m}^{2}$

- eGFR $\geq 30$ do $<60 \mathrm{ml} / \mathrm{min} / 1,73 \mathrm{~m}^{2}$

- eGFR $\geq 15 \mathrm{do}<30 \mathrm{ml} / \mathrm{min} / 1,73 \mathrm{~m}^{2}$

- eGFR $<15 \mathrm{ml} / \mathrm{min} / 1,73 \mathrm{~m}^{2}$

Pacjenci z hiperkaliemią:

- stężenie potasu >5,4 mmol// (przed terapią)

- stężenie potasu > 5,4 mmol/l (w trakcie terapii)

Pacjenci z obrzękiem naczynioruchowym w wywiadzie

Chorzy na cukrzycę (leczeni metforminą)

Pacjenci ze zwężeniem tętnicy nerkowej

Pacjenci z zaburzeniami czynności wątroby (skala Childa-Pugha*):

- stopień A

- stopień B

- stopień C

AspAT/AIAT $2 \times \uparrow$ powyżej normy *Skala Childa-Pugha - oceniane parametry to stężenie bilirubiny, stężenie albumin, wskaźnik protrombinowy/międzynarodowy współczynnik znormalizowany (INR, international normalized ratio), wodobrzu-
sze, encefalopatia wątrobowa
Bez modyfikacji dawki

Zalecana ostrożność

Niezalecane

Bez modyfikacji dawki

Zalecana ostrożność

Zalecana ostrożność

Niezalecane

Nie należy rozpoczynać leczenia

Modyfikacja dawek leków, w tym sakubitrilu/walsartanu lub rozważyć przerwanie leczenia

Przeciwwskazane

Zalecana ostrożność

Zalecana ostrożność

Monitorowanie czynności nerek

Bez modyfikacji dawki

Zalecana ostrożność

Przeciwwskazane

Zalecana ostrożność 
W przypadku innych leków często stosowanych u chorych z HF, takich jak furosemid, statyny, azotany, metformina, potas lub leki oszczędzające potas, inhibitory fosfodiesterazy czy niesteroidowe leki przeciwzapalne, należy zachować ostrożność w przypadku w terapii skojarzonej z sakubitrilem/walsartanem (tab. 8).

\section{W jakich grupach chorych należy zachować szczególną ostrożność?}

U pacjentów z HF występuje wiele innych współtowarzyszących chorób. Często wymagają one od lekarzy prowadzących zmiany terapii lub dawek stosowanych leków. Najczęstszymi współwystępującymi chorobami są niewydolność nerek i cukrzyca. Należy zwrócić szczególną uwagę na parametry funkcji nerek, aby odpowiednio dobrać dawkę leku i bezpiecznie prowadzić terapię. Trzeba również zwrócić uwagę na wartości glikemii u chorych na cukrzyce leczonych metformina, jako że terapia skojarzona z sakubitrilem/walsartanem może prowadzić do obniżenia glikemii. Rzadziej spotykanymi chorobami w tej grupie pacjentów są zaburzenia funkcji wątroby czy zwężenie tętnicy nerkowej (tab. 2). Szczególnej uwagi wymagają takie parametry, jak
BP i stężenie potasu. U pacjentów z HF częste są zarówno niskie wartości BP, jak i podwyższone stężenia potasu w surowicy (tab. 9).

\section{Podsumowanie}

Produkt leczniczy sakubitril/walsartan, mimo że jest nowym produktem na rynku farmaceutycznym, jest coraz częściej i chętniej stosowany w leczeniu chorych z objawową HFrEF. Zarówno w badaniach klinicznych, jak i w praktyce klinicznej wykazano, że sakubitril/walsartan jest lekiem bezpiecznym i dobrze tolerowanym $w$ grupie chorych z HF. Sakubitril/walsartan, dzięki swojemu innowacyjnemu, dwutorowemu mechanizmowi działania, wpływa nie tylko na ograniczenie objawów klinicznych, ale - co jest wyjątkowo istotne-zmniejsza śmiertelność, a także liczbę hospitalizacji w tej grupie chorych. Mimo wielu pozytywnych wyników i opinii tylko nieliczni chorzy w populacji polskiej korzystają z tej innowacyjnej terapii. Pozostaje mieć nadzieję, że wprowadzenie refundacji leku w niedługim czasie sprawi, że pozostali chorzy również będą mieli szansę na poprawę stanu klinicznego i rokowania.

\section{Abstract}

In a landmark multi-center, phase III, randomized controlled trial - PARADIGM-HF, that investigated long-term effects and safety of novel class of agents - angiotensin receptor antagonist/neprilisin inhibitor (ARNI) - LCZ696 (sacubitril/ /valsartan) in comparison with enalapril, clear clinical benefit was shown in patients with heart failure with reduced ejection fraction (HFrEF) who were subjected to sacubitril/valsartan. Sacubitril/valsartan (Entresto ${ }^{T M}$ ) has been available in Poland for the last two years. The present document is a practical guide for all those physicians who would like to initiate this new therapy for the first time and also for those have gathered so far some experience with Entresto ${ }^{T M}$.

Key words: heart failure with reduced ejection fraction, sacubitril/valsartan

Folia Cardiologica 2019; 14, 1: 95-105

\section{Piśmiennictwo}

1. Ponikowski P, Voors AA, Anker SD, et al. ESC Scientific Document Group. 2016 ESC Guidelines for the diagnosis and treatment of acute and chronic heart failure: The Task Force for the diagnosis and treatment of acute and chronic heart failure of the European Society of Cardiology (ESC)Developed with the special contribution of the Heart Failure Association (HFA) of the ESC. Eur Heart J. 2016; 37(27): 2129-2200, doi: 10.1093/eurheartj/ehw128, indexed in Pubmed: 27206819.

2. McMurray JJV, Packer M, Desai AS, et al. PARADIGM-HF Investigators and Committees. Angiotensin-neprilysin inhibition versus enalapril in heart failure. N EngI J Med. 2014; 371(11): 993-1004, doi: 10.1056/ /NEJMoa1409077, indexed in Pubmed: 25176015.

3. McMurray JJV, Packer M, Desai AS, et al. PARADIGM-HF Committees and Investigators. Dual angiotensin receptor and neprilysin inhibition as an alternative to angiotensin-converting enzyme inhibition in patients with chronic systolic heart failure: rationale for and design of the Prospective comparison of ARNI with ACEI to Determine Impact on Global Mortality and morbidity in Heart Failure trial (PARADIGM-HF). Eur J Heart Fail. 2013; 15(9): 1062-1073, doi: 10.1093/eurjhf/ /hft052, indexed in Pubmed: 23563576.

4. Entresto ${ }^{\mathrm{TM}}$ Charakterystyka Produktu Leczniczego, 2015. https:// //www.novartis.pl/system/files/product-info/entresto_chpl_2018_06. pdf (31.01.2019).

5. Lewis EF, Claggett BL, McMurray JJV, et al. Health-related quality of life outcomes in PARADIGM-HF. Circ Heart Fail. 2017; 10(8), doi: 10.1161/ /CIRCHEARTFAILURE.116.003430, indexed in Pubmed: 28784687.

6. Chandra A, Lewis EF, Claggett BL, et al. Effects of sacubitril/valsartan on physical and social activity limitations in patients with heart failure: a secondary analysis of the PARADIGM-HF trial. JAMA Cardiol. 2018; 3(6): 498-505, doi: 10.1001/jamacardio.2018.0398, indexed in Pubmed: 29617523.

7. Nadruz W, Claggett BL, McMurray JJ, et al. PARADIGM-HF Investigators and Committees, PARADIGM-HF Investigators and Coordinators. Angiotensin receptor neprilysin inhibition compared with enalapril 
on the risk of clinical progression in surviving patients with heart failure. Circulation. 2015; 131(1): 54-61, doi: 10.1161/CIRCULATIONAHA.114.013748, indexed in Pubmed: 25403646.

8. Wytyczne oceny technologii medycznych (HTA, ang. health technology assessment). Wersja 3.0. Agencja Oceny Technologii Medycznych i Taryfikacji. Warszawa, sierpień 2016. http://www.aotm.gov.pl/www/ /wp-content/uploads/wytyczne_hta/2016/20160913_Wytyczne_ AOTMiT.pdf (31.01.2019).

9. Feature story. Real-world evidence: perceptions of cardiologists. https://www.acc.org/latest-in-cardiology/articles/2018/02/13/ /14/42/feature-story-real-world-evidence-perceptions-of-cardiologists (31.01.2019).

10. Du X, Khamitova A, Kyhlstedt M, et al. Utilisation of real-world data from heart failure registries in OECD countries - a systematic review. IJC Heart \& Vasculature. 2018; 19: 90-97, doi: 10.1016/j.ijcha.2018.02.006.

11. Aimo A, Seghieri C, Nuti S, et al. Building medical knowledge from real world registries: the case of heart failure. IJC Heart \& Vasculature. 2018; 19: 98-99, doi: 10.1016/j.ijcha.2018.03.008.

12. Greene SJ, Butler J, Albert NM, et al. Medical therapy for heart failure with reduced ejection fraction: the CHAMP-HF Registry. J Am Coll Cardiol. 2018; 72(4): 351-366, doi: 10.1016/j.jacc.2018.04.070, indexed in Pubmed: 30025570.

13. Wachter R et al. Dosing Patterns and Evolution of Clinical Parameters in Patients Prescribed Sacubitril /Valsartan in Germany. Poster presentation at: American Heart Association Scientific Sessions 2017. Nov 11-15, Anaheim, CA. https://www.ahajournals.org/doi/ /abs/10.1161/circ.136.suppl_1.15751 (31.01.2019).
14. Wachter R, Viriato D, Klebs S, et al. Early insights into the characteristics and evolution of clinical parameters in a cohort of patients prescribed sacubitril/valsartan in Germany. Postgrad Med. 2018; 130(3): 308-316, doi: 10.1080/00325481.2018.1442090, indexed in Pubmed: 29446691.

15. Canu A, et al. Results of a single center experience on 200 consecutive patients treated with Entresto (sacubitril/valsartan). Eur J Heart Fail. 2017; 19: 413-414.

16. Bastien N, Haddad H, Bergeron S, et al. The PARASAIL study - patient reported outcomes from the Canadian real-world experience use of sacubitril/valsartan in patients with heart failure and reduced ejection fraction. Canadian J Cardiol. 2017; 33(10): S162-S163, doi: 10.1016/j.cjca.2017.07.316.

17. Martens $\mathrm{P}$, Beliën $\mathrm{H}$, Dupont $\mathrm{M}$, et al. Insights into implementation of sacubitril/valsartan into clinical practice. ESC Heart Fail. 2018; 5(3): 275-283, doi: 10.1002/ehf2.12258, indexed in Pubmed: 29464879.

18. Murray G, et al. The use of sacubitril/valsartan: a real world experience in a high volume specialist heart failure service. Heart. 2017; 103: A8-A9.

19. Kałużna-Oleksy M, Kolasa J, Migaj J, et al. Pierwsze doświadczenia kliniczne z przedstawicielem nowej grupy leków ARNI (sakubitril/ /walsartan) u pacjentów z niewydolnością serca z obniżoną frakcją wyrzutową lewej komory w Polsce. Kardiol Pol. 2018; 76(2): 381-387, doi: 10.5603/kp.a2017.0230, indexed in Pubmed: 29192956.

20. Antol DD, Casebeer AW, DeClue RW, et al. An early view of real-world patient response to sacubitril/valsartan: a retrospective study of patients with heart failure with reduced ejection fraction. Adv Ther. 2018; 35(6): 785-795, doi: 10.1007/s12325-018-0710-4, indexed in Pubmed: 29777521. 